\title{
A Review of Multiliteracies Pedagogy in Primary Classrooms
}

\author{
PIRJO KULJU \\ University of Tampere \\ REIJO KUPIAINEN \\ University of Tampere, \\ Finland and Norwegian University of Science and Technology
}

ANGELA M. WISEMAN
North Carolina State University

ANNE JYRKIÄINEN
University of Tampere
KIRSI-LIISA KOSKINEN-SINISALO
University of Tampere
MARITA MÄKINEN
University of Tampere

Abstract

In the digital era, students are walking new literacy paths. For this reason, there is a need to explore evolving literacy practices in school pedagogy. This is often addressed by the expanding use of the concept of multiliteracies. This article reviews studies $(\mathrm{N}=67)$ of multiliteracies pedagogy. The main purpose was to explore how the concept of multiliteracies has been used and understood in primary classroom research. The findings indicate that the studies often took into account both the multimodality of meaning-making and the diversity of learners. Recommendations are made for future multiliteracies studies to strengthen the pedagogical practices.

\section{Introduction}

This paper presents a systematic analysis of research articles on multiliteracies pedagogy in primary classrooms. In twenty-first-century classrooms, the concept of multiliteracies posits that "text," which humans use to make meaning in their everyday lives, vary depending on social context and prevailing modes of meaning-making (image, sound, writing, gesture, speech, drama etc.) (Kalantzis \& Cope, 2012; Hassett \& Curwood, 2009). Digital communication has further increased the ways in which humans interact and understand meanings. New technologies regularly transform and redefine what it means to be literate (Gee, 2003), requiring teachers to become more knowledgeable about how different texts can be used in the classroom (Anstey \& Bull, 2010).

In order to understand multiliteracies and its role in teaching and learning in schools, the concept of literacy must be recognized as shifting and therefore reconceptualized in our changing society (Anstey \& Bull, 2006). Rapidly evolving societal, 
technological, cultural and economic influences also change the texts we use and our views of literacy. The use of literacy in everyday life depends on context and purpose, and literacy and meaning-making are multimodal in which written-linguistic modes of meaning can be complemented by oral, visual, audio, gestural, tactile and spatial patterns of meaning (Kalantzis \& Cope, 2012). In these circumstances, literacy has become increasingly deictic, multifaceted and multimodal (e.g. Leu, Kinzer, Coiro, Castek \& Henry, 2004; Kress, 2003; Pahl, 2005; Anstey \& Bull, 2006; Mills, 2011).

Additionally, our classrooms have become more diverse by virtue of students' differing social roles, gender and ethnic differences, identity politics, life experiences and cultural settings. For this reason, it is essential that teachers take account of varied meaning-making patterns and practices in terms of the modes and social diversity of learning and communicating.

Theoretically, a multiliteracies pedagogy is connected to social semiotics and originated from Halliday's (1978) functional linguistics, focusing on meaning-making through language and what people do with that language. Social semiotics addresses how meanings are embedded in social practices and conveyed through semiotic resources called modes (Kress, 2010). This broadens the concept of text in the context of human interaction and meaning-making, emphasizing semiotic resource and mode as key terms in meaningmaking (van Leeuwen, 2005).

The multiliteracies approach to education evolved from the manifesto of the New London Group (NLG) (1996), entitled A Pedagogy of Multiliteracies: Designing Social Futures. In a contemporary context, multiliteracies can be considered a "new basics" of literacy learning in a world characterized by multimodal communications and social diversity (Kalantzis \& Cope, 2012). There is a lifeworld of students, in which they are both audiences and producers of texts of various kinds, using different media devices and platforms. In multiliteracies pedagogy, reading a text involves reshaping meaning. In the theory proposed by the NLG (New London Group, 1996), this is understood as "design," which "draws attention to how learners are both inheritors of patterns and conventions for making meaning and active designers of new meanings" (Mills, 2006a, p. 133). In other words, design refers both to the structure of the product and to the process of designing it; in this sense, both reading and writing are productive activities and forms of designing (New London Group, 1996). In multiliteracies pedagogy, the meaning-making design process involves combining available designs as resources for meaning (e.g. artefacts of communication, tools for representation, potential resources); designing (meaning-making work and practice) and the re-designed (new available designs) (New London Group, 1996; Kalantzis \& Cope, 2012).

Multiliteracies pedagogy builds on more traditional approaches of writtenlinguistic meaning-making, and extends learning to incorporate what is new in the current environment (Kalantzis \& Cope, 2012). Although this expands our understanding of literacies, reading still incorporates sociocultural and contextual dimensions along with cognitive, affective and visual processes - for instance, the interaction between reader and text does not occur without what is traditionally referred to as decoding (Walsh, 2006). We concur with Freebody and Luke's (1990) view that no single perspective can comprehend how students "use texts effectively in their own individual and collective interests across a range of discourses, texts, and tasks" (p. 8). Different theoretical aspects of reading and literacy are intertwined in primary education curricula. In Finland, for example, the 
curricula have included at least traces of cognitive, sociocognitive, functional and sociocultural theories (Kauppinen, 2010). Similarly, distinct theoretical backgrounds have resulted in differing pedagogical practices in writing. In a pedagogical context, Ivanič (2004) has identified discourses of writing that range from skills, genre and process discourses to discourses of creativity, social practice and sociopolitics. Traditionally, however, in both practice and research, reading and writing are commonly seen as separate processes and texts as static genres.

Beyond the more traditional theoretical underpinnings, changing literacy practices and the NLG manifesto have affected not only literacy research but also education policy, with international implementation of multiliteracies in core curricula. For instance, the Ontario curriculum focuses on "students' ability to use their knowledge and skills in listening, speaking, reading, writing, viewing, and representing to understand, critically analyze, and communicate a broad range of information and ideas from and about their multicultural, multimedia environment" (Ontario Ministry of Education, 2006). In Australia, the national standards require that children in year 1 begin to create short "imaginative and informative texts" that include multimodal elements and also use texts with supporting images (Australian Curriculum, Assessment, and Reporting Authority, n.d.). In Finland, the new Finnish Core Curriculum for Basic Education (NCC, 2016) includes multiliteracy as a transversal competence. The Common Core State Standards in the US include a focus on using technology and digital media as a way to access information and communicate knowledge in ways that support students' learning across various modes (NGA \& CCSO, 2010).

However, challenges remain in applying the multiliteracies approach to school practices. First of all, the theoretical concept of multiliteracies is complex, and, in fact, Palsa and Ruokamo (2015) concluded that use of the concept in research differs from the concept of multiliteracy as applied in the Finnish core curriculum. In particular, while the theoretical concept refers more to a pedagogical approach, the concept is applied in practice as a set of communication abilities. Secondly, despite the wide range of literacy studies focusing on multiliteracies, there is an overall lack of systemic analyses and reviews of multiliteracies being applied in schools and this emphasizes the need for this analysis, which is beginning at the primary level. In exploring how the concept of multiliteracies has been applied to pedagogy in primary education, the analysis presented here will contribute both to discussion of multiliteracies pedagogy and to future multiliteracies research in education.

\section{Method}

To gain an overview of implementation of multiliteracies in the classroom, we conducted a systematic literature review. According to Finfgeld-Connett (2014), systematic analysis responds to questions that are difficult to answer using quantitative methods or findings from isolated qualitative investigations. As systematic reviews are also designed to identify existing gaps in the field of research and to make practical recommendations (Pittaway, 2007), this method serves the aims of the present study. The guiding research question was as follows: How has the concept of multiliteracies been used and understood in primary classroom research?

The data in this study included peer-reviewed studies that focused on multiliteracies in the primary classroom. The data were retrieved using both ERIC and the Academic 
Search Complete search engine; ERIC because it is an important education research database and Academic Search Complete because it allowed us to expand our search to include social sciences and the humanities. In the first phase of the study, the following search was used, with modifications of Boolean operators for different platforms, such as multiliterac* OR multiple literac* OR multimodal literac* AND elementary OR primary AND reading. We accepted multimodal literacy as a keyword because it is often used synonymously with multiliteracies. We also used the search term reading in order to link the articles on texts and literacy but not particularly to reading comprehension or reading research. Therefore, as a search word reading does not have any emphasis and our study is focused on multiliteracies in a classroom context.

The search for articles extended through 2014, and the initial process yielded 338 articles. These articles were reviewed on the basis of the inclusion and exclusion criteria presented in Table 1. Based on these criteria, several articles were excluded at this point, leaving 106. To ensure reliability, we then carefully read the remaining 106 articles and discussed problematic cases for inclusion or exclusion. For instance, we discussed whether summer school programs would count as classroom contexts. As contexts and curricula are often quite different, we decided to exclude them from the list. At this point, one of the main criteria for exclusion was if the article did not include empirical data focusing on students in primary school classrooms. After this final step, we were left with a final sample of 67 articles (Appendix 1) from 1997 to 2014.

Table 1

\section{Inclusion and exclusion criteria}

\begin{tabular}{|l|l|}
\hline Inclusion criteria & Exclusion criteria \\
\hline Peer-reviewed & Not peer-reviewed \\
Published in 2014 or earlier & Not written in English \\
Written in English & Books and reviews \\
$\begin{array}{l}\text { Focuses on multiliteracies (or multiple } \\
\text { or multimodal literacy) and reading in } \\
\text { primary classrooms }\end{array}$ & $\begin{array}{l}\text { Focuses on daycare, secondary } \\
\text { classrooms, preservice and inservice } \\
\text { teachers or professional development } \\
\text { of teachers }\end{array}$ \\
\hline
\end{tabular}

Despite this careful identification of articles, we may not have located all those fulfilling our criteria. However, we believe the sample is large enough for a representative review of multiliteracies pedagogy in primary classrooms. While we also recognize that there have been many further relevant publications since 2014, we are confident that this article provides an essential archival perspective on foundational issues.

For the purposes of data analysis, we applied the principles of qualitative content analysis in systematic reviews. To begin, the coding categories were defined inductively 
by studying a subset of articles and drawing inferences about organizing codes (cf. Finfgeld-Connett, 2014). The coding template was then constructed as follows: article topic, definition of multiliteracies, theoretical and/or pedagogical concept connections, main research questions or aims, method and data (including country of data collection and the children's age), media of modes (e.g. claymation movie, video, book, comic, photograph) and key recommendations in relation to multiliteracies pedagogy. Based on Kalantzis and Cope's (2012) distinctions of meaning-making, the articles were also classified according to 1) multimodality, 2) diversity in global connectedness (cultural, social and linguistic diversity) or 3) both.

The research team jointly coded two articles (Mills, 2007a; Ranker, 2007) to clarify the criteria for the categories. We selected one article as an exemplar (Ranker, 2007) and one that was more challenging for category determination (Mills, 2007a). A clarifying conversation allowed the team to communicate understandings of the categories, and each of the present authors then coded a set of articles. We continued to discuss problematic cases; for example, the methodology and methods or the country of data collection were not always clearly specified.

After coding, each topic was analyzed according to the principles of qualitative content analysis. This is a flexible method of data analysis that can range from impressionistic interpretation to highly systematic analysis (Hsieh \& Shannon, 2005; Finfgeld-Connet, 2014). The results were reported in the form of figures and tables and through descriptive analyses. In this paper, we concentrate on concept definition, theoretical approaches, methods and data, as well as on article topics and the key aspects of cultural, social and linguistic diversity.

\section{Definition of Multiliteracies}

Results

Although the definition of multiliteracies was not always clearly stated, the review confirms that the work of the NLG influenced almost all of the articles, most of which either mention the NLG or refer to works by Bill Cope and Mary Kalantzis. In particular, many authors cited their edited volume Multiliteracies: Literacy Learning and the Design of Social Futures (2000), which is a further elaboration of the theory of multiliteracies. Kalantzis and Cope were also members of the NLG. An article by Callow (2003, np) provides one example of a clear definition built on the work of the NLG:

The term multiliteracies acknowledges the multiplicity of meaning-making modes (visual, textual, audio, etc.) as well as the wider social contexts of these modes, from diverse local settings to global communities.

This definition follows Kalantzis and Cope (2012) in highlighting two major aspects of meaning-making: multimodality and diversity. Thirty-six of the reviewed articles focused on multimodality; six focused more specifically on cultural, social and linguistic diversity, and twenty-five addressed aspects of both multimodality and diversity.

The data also confirmed the importance of design as an aspect of multiliteracies (e.g. Hesterman, 2011a; Mills, 2006b; Ranker, 2007). This refers both to the sign-making, reading and production of texts that use different modes of communication (Kress, 2010) and to the "designing of social futures" articulated in the NLG manifesto. The manifesto 
itself is also a political statement, in which the future is seen possible to imagine and design as something that allow all students to participate in public and community life.

Theoretical approaches. Because the reviewed articles share basic ideas developed by the NLG, we can identify some general theoretical assumptions that they explicitly or implicitly entail. In many cases, social semiotics (van Leeuwen, 2005; Kress, 2003, 2010), was seen as an important theoretical approach (e.g. Callow, 2006; Marshall \& Toohey, 2010; Mavers, 2009). Secondly, several articles referred to multimodality in their theoretical framework; among these, Hughes and Morrison (2014, p. 612) defined multimodality as "meaning-making through many representational modes (Jewitt \& Kress, 2003), digital and social". According to Callow (2006, p. 7), multimodal refers to "texts which include spoken, written, visual, aural and interactive aspects".

Along with social semiotics and multimodality, another important theoretical approach relating to the definition of multiliteracies was Lev Vygotsky's sociocultural theory (Vygotsky, 1962), also associated with Jean Lave and Etiene Wenger (1991) (e.g. Ridgewell \& Exley, 2011; Pantaleo, 2013; Cumming-Potvin, 2007). The central idea of sociocultural theory is that learning occurs through relations with others rather than by means of purely individual cognitive processing. As one example, Hughes and Morrison (2014) took account of this social dimension when studying multiliteracies pedagogy in the development of English language learners' identities as writers.

The data also reveal the strong influence of the sociolinguistic approaches of Halliday (1993) and Gee (1996) (e.g. Doherty, 2002; Mills, 2011; Ranker, 2008). Social linguistics theory (Gee, 1996, 2015) is important for multiliteracies research because it changes the understanding of situated contexts and their impact on learning. In some of the reviewed articles, researchers applied New Literacy Studies theory to social linguistics (e.g. Wohlwend, 2009; Mills \& Exley, 2014), following James Paul Gee's (1996; 2015) argument concerning social and cultural approaches to language, literacy and learning. New Literacy Studies (e.g. Gee, 1996; 2003; Mills, 2016; Lankshear, 1997; Lankshear \& Knobel, 2003) emphasizes literacy practices that involve reading and writing in cultural contexts. For example, Hill (2010) explored the ways in which young children use new forms of literacy at home and in the community, as well as in educational settings.

Some authors emphasized this social diversity by using theories such as additive bilingualism (Lambert, 1974) or multilingualism (Cenoz \& Genesee, 1998); third space theory (Gutiérrez, 2008); critical theory (Luke \& Freebody, 1997) and theories of communicative action (Habermas, 1981) as well as situated learning theory (Lave \& Wenger, 1991). Here, the emphasis on equal opportunities celebrates diversity and enhances the participation of all students in classroom activities. However, although inclusive education has embraced the notion of social justice and equal participation, the inclusive turn in education was not mentioned as a driving theory (cf. Forlin, 2010; Ainscow, Conteh, Dyson \& Gallanaugh, 2010).

According to Lankshear and Knobel (2006), literacies are understood only when they are situated within social, cultural and historical contexts and connected to social identities. The articles in our dataset shared the perspective that education and literacy are socially situated as the constructions of social groups rather than of individuals and cognitive skills alone. Kitson et al. (2007) provide and exemplar of these starting points as they examined how multiple literacies are constructed through teacher-student interactions. 
Multiliteracies pedagogy should take into account not only literacy practices in the school environment but also those at home and in various other cultural contexts and situations relating, for example, to popular culture.

\section{Methods}

The reviewed studies were typically qualitative, with an emphasis on observational data collection (e.g. Callow, 2006; Ranker, 2007; Mills, 2007a; Kervin, 2009; Ikpeze, 2012). The use of multiple data sources was also common; for example, as well as collecting school-wide observational data from a year-long study, Palmer (2010) conducted interviews with parents and staff members. Zammit's (2011) study included field notes, observation schedules, student work samples, students' self-assessment journals and teacher reflections. In addition, some studies included descriptions of different activities, such as classroom activities (Pendleton, 2013), learning communities (Lotherington, 2007), rewriting situations and children's products (Lotherington \& Chow, 2006) and literacy programs (Doherty, 2002).

Ethnographic methods were also used (e.g. Rossi, 1997; Del-Castillo, GarciaVarela \& Lacasa, 2003; Kitson, Fletcher \& Kearney, 2007; Pahl, 2007; Hesterman, 2011a, 2011b, 2013). For example, Mills (2007a) explored students' access to multiliteracies at a suburban state school in Queensland, Australia, by using critical ethnography drawing on observational data, continuous audio-visual recordings, field notes and self-reflective journals. Quantitative methods were used in only two of the reviewed articles. Koren, Klavir and Gorodetsky (2005) studied students' multimodal representations of scientific knowledge, and Grimes and Warschauer (2008) used triangulation combining quantitative and qualitative data in their study of laptop use among 554 students. The most common research setting was Australia $(\mathrm{N}=24)$, followed by the US $(\mathrm{N}=20)$ and Canada $(\mathrm{N}=13)$. Only a few of the reviewed studies were conducted in other countries.

Article topics can be divided into five main categories; these are shown in Figure 1 , along with the main aspects of diversity in each category.

Topics: Writing and text production. The category of writing and text production was a common topic in the reviewed articles. Produced texts were typically multimodal and included digital videos (Ranker, 2008), TV commercials (Kervin, 2009), web pages (Merchant, 2005; Del-Castillo, Garcia-Varela \& Lacasa, 2003) and traditional stories redesigned with new technologies (e.g. Lotherington, 2007; Lotherington \& Chow, 2006). For this reason, the production process often drew on digital media and communication.

Topics: ICT. Although text production often employed information and communications technology (ICT) and topic areas tended to overlap, some articles reflected a particular focus on ICT in teaching multiliteracies, as in the work of Hersteman (2011a, 2011b, 2013). In addition, Ridgewell and Exley (2011) studied forum-based netspeak (the communication style found in online forums) in the context of scientific learning. 


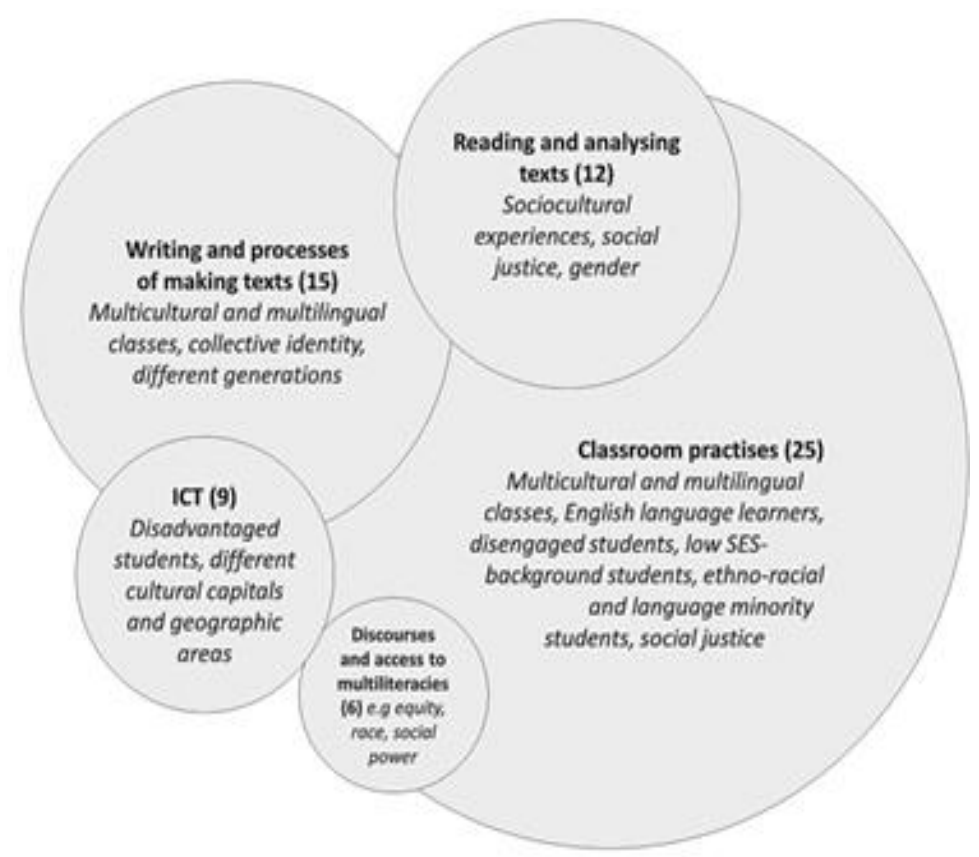

Figure 1. Topic areas and aspects of diversity in the reviewed articles $(\mathrm{N}=67)$.

Topics: Reading and analyzing texts. Studies of reading and analyzing texts included those that focused on students' interpretations of texts (e.g. Ajay, 2011; Callow, 2006; Serafini \& Ladd, 2008). Interestingly, several of the studies of text analysis concerned how adults interpret students' texts. For example, Mills (2011) performed a genre analysis of students' claymation movies, and Albers (2009) and Pahl (2007, 2009) sought to understand multimodal children's texts such as drawings or panorama boxes. In an exceptional thematic text analysis, Fisher, Albers and Frederic (2014) explored punitive literacy practices in the classroom by analyzing student's drawings of situations in which they had misbehaved. All of the texts in this category were multimodal, with an emphasis on visuals (e.g. comic books, picture books, animated videos, claymation movies, drawings, panorama boxes and PowerPoint presentations).

Topics: Classroom practices. A significant number of the reviewed studies $(\mathrm{N}=$ 25) were classified as relating to classroom practices (Figure 1). For example, Siegel, Kontovourki, Schmier and Enriquez (2008) studied the literacy practices and cultural models constituting the mandated balanced literacy curriculum, and Wohlwend (2009) studied how children engage with new literacies and multimodal semiotic practices using available classroom materials. Perspectives in this category were wide ranging, and the topics covered the integration of science, math and technology literacies (Pendleton, 2013) and the conceptualization of literacy and literacy practices for children with specific language impairments (Lawson, Layton, Goldbart, Lacey \& Miller, 2012).

Reading pedagogy was foregrounded, as for example in Cumming-Potvin's (2007) study of progress in literacy within the multiliteracies pedagogy and in Ryan and Anstey's (2003) work on supporting students' self-knowledge of reading. Similarly, Hughes and Morrison (2014) explored the writer identities of English language learners, and identity among English language learners was also studied by Cummins, Bismilla, Chow, Cohen, 
Giampapa, Leoni, Sandhu, and Sastri (2005). Student engagement was studied especially among students with low socioeconomical background (SES) (Zammit, 2011) and disengaged students (Ikpeze, 2012). Thus, besides different types of literacy practices, these articles were related to instruction, support and scaffolding in classrooms, student engagement and identity, conceptualization of literacy, learning environment and curriculum.

Topics: Discourses and access to multiliteracies and other aspects of diversity. There were six studies in the data, which we interpreted mainly as perspectives on diversity, coding them as "Discourses and access to multiliteracies" (see Figure 1). They included four studies by Kathy Mills, who has studied discourse, diversity and access to multiliteracies in culturally diverse classrooms (Mills, 2006a, 2006b, 2007a, 2007b). The other two studies include Comber, Thomson and Wells (2001), exploring social action and power in a local urban renewal project, and Palmer (2010), who examined dual-language education in terms of race and equity.

Beyond these six studies, aspects of diversity were sometimes connected to multimodal meaning-making. For example, text production (Figure 1) was sometimes associated with concepts of diversity, notably in Lotherington (2007) and Lotherington and Chow (2008), as well as in Lotherington, Holland, Sotoudeh and Zentena (2008), who focused on multilingual and multicultural classrooms. Del-Castillo et al. (2003) linked the construction of a website about violence to collective identity, and there was a similar community dimension in Marshal and Toohey's (2010) exploration of intergenerational storytelling. In the studies that focused more on ICT, considerations of diversity were less common, although some important connections were made between technology and diversity. For example, Doherty (2002) studied technological skills among urban Aboriginal students, and Hill (2010) explored different cultural capitals and geographic areas.

Diversity was less often considered in studies of reading and analyzing texts (Figure 1) than in those focusing on text production. However, Ajay (2011) focused on students' sociocultural experiences, and Albers, Frederick and Cowan (2009) looked at gender features in students' drawings while Callow (2006) emphasized social justice issues in his study of visual metalanguage.

Among studies of classroom practices (Figure 1), diversity was often linked to multilingualism. Practices were studied in multilingual classrooms (Cummins, Bismilla, Cohen, Giampapa \& Leoni, 2005, p. 41) and among English language learners (e.g. Hughes \& Morrison, 2014) or ethno-racial and language minority students (Taylor, Bernhard \& Cummins, 2008). Crafton, Silvers and Brennan's (2009) work on multiliteracies instruction in a multi-ethnic class emphasized social justice as an integral aspect of diversity. Similarly, Silvers, Shorey and Crafton (2010) involved an entire class in a collective social action project to help victims of Hurricane Katrina after it struck the Southeast United States.

\section{Discussion}

In the past 20 years, literacy has increasingly been viewed as a socially constructed phenomenon; according to Kitson, Fletscher and Kearny, "what counts as literacy is locally and situationally defined through the action of members in a social group" (2007, p. 30), 
and language is described in holistic terms as a set of socially and culturally situated practices for meaning-making (e.g. Wedin, 2010). The concept of multiliteracies broadens our understanding of what constitutes a text and raises the question of the relationship between language, literacy and education. For this reason, we set out to study multiliteracies pedagogy in primary classrooms, focusing on how the concept has been used and understood. As multiliteracies is widely used in research, we found it relevant to explore how the new literacy environment and multiliteracies pedagogy is understood, especially among primary students. In this section, we will present some of our key findings, along with directions for future research.

Our analysis supports Palsa's and Ruokamo's (2015) view that the NLG manifesto is seminal in that it provides the theoretical basis for multiliteracies and continues to influence current research. The reviewed articles took account of the multimodal nature of the texts and placed more emphasis than traditional literacy research on visual and digital texts (cf. Kulju et al., 2017). However, beyond the integration of technology and multiple modalities, multiliteracies pedagogy should encompass the wide range of linguistic, social, racial, cultural, sexual and gendered identities of children in our classrooms (Boyd \& Brock, 2015). The shared perspective confirmed here was that education and literacy are socially situated and grounded in constructions of social groups rather than in individual and cognitive skills alone.

In our data, diversity usually referred to multicultural and multilingual classes and to students for whom English was a second language. In some cases, diversity referred to students who are disadvantaged due to experiencing poverty. In future studies, this aspect of diversity should be extended to specific social and cultural issues and to gender diversity. For instance, we see potential in combining feminist or queer theories to provide important perspectives of text production or identification as influencing literacy practices (Blaise \& Taylor, 2012; Cherland \& Harper, 2007). Even linguistic resources could be more widely taken into account in terms of different written and spoken forms of language in certain social groups. As pointed out by the NLG (1996), one of the most important skill that the students need to learn is the ability to negotiate regional, ethnic or class-based dialects or cross-cultural discourses, and non-English speaking countries or societies should also be included. This expanded view of diversity in the multiliteracies pedagogy could also extend the possibilities of inclusivity in education, placing similar emphasis on social justice and equal participation (cf. Forlin, 2010; Ainscow, Conteh, Dyson \& Gallanaugh, 2010).

Most of the studies reviewed here were qualitative case studies based on observational data. In developing existing understandings of multiliteracies pedagogies, we advocate the use of more varied methods, including expanding qualitative methods and incorporating quantitative and mixed methods studies. Combinations of quantitative and qualitative studies could bring new insights into the research in this area. Quantitative methods could contribute to the evaluation of learning outcomes of multiliteracies pedagogy, and serve in taking account of background variables related to the social diversity of learners. Data collection might be broadened to, for example, video diaries, to capture students' voice more effectively (cf. Kulju et al., 2017).

Qualitative research can also provide a formative evaluation for quantitative measures (Maxwell, 2012). Researchers on multiliteracies pedagogy should thus also consider the indications of qualitative studies to determine what should be researched on a large scale. In addition, collaboration across scientific fields such as education, psychology, 
linguistics, digital studies, literature and social sciences may provide insight into various methodologies as well as into different aspects of multimodality and diversity in multiliteracies pedagogy (cf. Kulju et al., 2017).

The reviewed studies covered a broad range of issues related to multiliteracies pedagogy. Interestingly, and in contrast to more traditional literacy research, text production took precedence over text reception. Additionally, reading was studied mainly from the perspective of text analysis, as a concequence of which it seems that the multiliteracies approach neglects the skills aspect of reading. This is probably related to the emphasis on design, referring both to the sign-making, reading and writing texts that use different modes, and to the "designing of social futures", as expressed in the NLG manifesto. In other words, reading and writing seem to blend, which creates challenges in planning and evaluating learning processes at school.

This also raises the question of learning within multiliteracies pedagogy - that is, how students develop their literacy skills and how we assess their learning. Future studies should strive to capture in greater detail the features of project-type reading and writing action in schools and their relation to curriculum aims in order to support the development of school pedagogy. In saying this, we should reiterate that this paper and multiliteracies concerns pedagogy rather than skills.

A few limitations of this study should be noted, relating mainly to data search. The definition of search terms was a complex process; we constrained the search by using the term reading in the original process, which may have limited the selection of papers. In addition, research using the term multiliteracy as a keyword is only now emerging in Finland, following recent changes in the national curriculum and the translated terms it employs. Additionally, several of the papers were less specific about their theoretical or methodological bases, which created challenges for the analyses. Despite these limitations, however, this study is the first systematic review to concentrate on multiliteracies pedagogy at the primary level and it may contribute to future research on multiliteracies classroom practices. Moving forward, it seems important to continue the review through 2018 to identify changes and trends in recent research. However, multiliteracies pedagogy is a continuum, and while new technologies emerge and become part of everyday schooling, the grounding principles of multiliteracies remain unchanged. As an alternative to monocultural and book-centered education, multiliteracies pedagogy foregrounds meaning making, using different modes of communication in diverse contexts.

\section{Conclusion}

Since the publication of the NLG manifesto in 1996, academic discussions about theoretical perspectives, pedagogical possibilities, criticism about literacy teaching and learning and social diversity at schools have increased enormously. Leander and Boldt (2013) noted that 'A Pedagogy of Multiliteracies' has been foundational to doctoral programs, published research, conference presentations and papers as the central manifesto of the new literacies movement.

As the present findings indicate, a body of predominantly qualitative studies conducted in primary classrooms has also been influenced by the New London Group's manifesto. These studies explore the multimodality of meaning-making in both text analysis and in text production and acknowledge the diversity of learners. Future studies should continue this collaboration between students, teachers and researchers (cf. McClay, 
2006) in order to understand changing literacy practices. To properly develop this "new basics" of literacy education, that collaboration should also extend to families and communities. By expanding the methodology, aspects of diversity and taking more effectively into account the social practices that are continually moving, changing and unfolding in spaces (Mills 2016) we can hope to develop a pedagogy that bridges old and new or evolving literacy practices and environments.

\section{References}

Ainscow, M., Conteh, J., Dyson, A., \& Gallanaugh, F. (2010). Children in primary education: Demography, culture, diversity, inclusion. In R. Alexander, C. Doddington, J. Gray, L. Hargreaves, \& R. Kershner (Eds.), The Cambridge primary review research surveys (pp. 195-216). London: Routledge.

Ajayi, L. (2011). A multiliteracies pedagogy: Exploring semiotic possibilities of a Disney video in a third grade diverse classroom. The Urban Review, 43(3), 396-413.

Albers, P. (2009). Reading students' visual texts created in English language arts classrooms. Language Arts Journal of Michigan, 25(1), 6-16. https://doi.org/10.9707/2168-149X.1083

Albers, P., Frederick, T., \& Cowan, K. (2009). Features of gender: An analysis of the visual texts of third grade students. Journal of Early Childhood Literacy, 9(2), 243-269. https://doi.org/10.1177/1468798409105588

Anstey, M., \& Bull, G. (2006). Teaching and learning multiliteracies: Changing times, changing literacies. Newark, DE: International Reading Association.

Anstey, M., \& Bull, G. (2010). Helping teachers to explore multimodal texts. Curriculum Leadership Journal, 8(16). Retrieved from http://www.curriculum.edu.au/leader/helping_teachers_to_explore_multimodal_te xts 31522.html?issueID=12141

Australian Curriculum, Assessment, and Reporting Authority (n.d.). Australian

Curriculum. Retrieved from http://www.australiancurriculum.edu.au/

Blaise, M., \& Taylor, A. (2012). Using queer theory to rethink gender equity in early childhood education. YC Young Children, 67(1), 88.

Boyd, F. B., \& Brock, C. H. (2014). Social diversity within multiliteracies: Complexity in teaching and learning. New York: Taylor and Francis.

Callow, J. (2003). Talking about visual texts with students. Reading Online, 6(8), 1-16.

Callow, J. (2006). Images, politics and multiliteracies: Using a visual metalanguage. Australian Journal of Language and Literacy, 29(1), 7-23.

Cenoz, J., \& Genesee, F. (1998). Psycholinguistic perspectives on multilingualism and multilingual education. In J. Cenoz \& F. Genesee (Eds.), Beyond bilingualism: Multilingualism and multilingual education (pp. 16-32). Clevedon, UK: Multilingual Matters.

Cherland, M. R., \& Harper, H. J. (2007). Advocacy research in literacy education:

Seeking higher ground. New York: Routledge.

Comber, B., Thomson, P., \& Wells, M. (2001). Critical literacy finds a "place": Writing and social action in a low-income Australian grade 2/3 classroom. The Elementary School Journal, 101(4), 451-464.

Cope, B., \& Kalantzis, M. (Eds.) (2000). Multiliteracies. literacy learning and the design of social futures. New York: Routledge. 
Crafton, L. K., Silvers, P., \& Brennan, M. (2009). Creating a critical multiliteracies curriculum: Repositioning art in the early childhood classroom. In M. Narey (Ed.), Making meaning: Constructing multimodal perspectives on language, literacy and learning through art-based early childhood education (pp. 31-51). Springer US. https://doi.org/10.1007/978-0-387-87539-2_3

Cumming-Potvin, W. (2007). Scaffolding, multiliteracies, and reading circles. Canadian Journal of Education/Revue Canadienne de l'Education, 30(2), 483-507. https://doi.org/10.2307/20466647

Cummins, J., Bismilla, V., Cohen, S., Giampapa, F., \& Leoni, L. (2005). Rethinking literacy instruction in multilingual classrooms. Orbit, 36(1), 22-26.

Cummins, J., Bismilla, V., Chow, P., Cohen, S., Giampapa, F., Leoni, L., ... Sastri, P. (2005). Affirming identity in multilingual classrooms. Educational Leadership, 63(1), 38-43.

Del-Castillo, H., García-Varela, A. B., \& Lacasa, P. (2003). Literacies through media: identity and discourse in the process of constructing a web site. International Journal of Educational Research, 39(8), 885-891. https://doi.org/10.1016/j.ijer.2004.11.010

Doherty, C. (2002). Extending horizons: Critical technological literacy for urban Aboriginal students. Journal of Adolescent \& Adult Literacy, 46(1), 50-59.

Finfgeld-Connett, D. (2014). Use of content analysis to conduct knowledge-building and theory-generating qualitative systematic review. Qualitative Research, 14(3), 341-352. https://doi.org/10.1177/1468794113481790

Fisher, T. R., Albers, P., \& Frederick, T. G. (2014). When pictures aren't pretty: Deconstructing punitive literacy practices. Journal of Early Childhood Literacy, 14(3), 291-318. https://doi.org/10.1177/1468798413485267

Forlin, C. (2010). Teacher education for inclusion: Changing paradigms and innovative approaches. New York: Routledge.

Freebody, P. \& Luke, A. (1990) Literacies programs: Debates and demands in cultural context. Prospect, 5, 7-16.

Gee, J. P. (1996). Social linguistics and literacies: Ideology in discourses (2nd ed.). London: Routledge.

Gee, J. P. (2003). What video games have to teach us about learning and literacy. New York: Palgrave Macmillan.

Gee, J. P. (2015). Social linguistics and literacies: ideology in discourses (5th ed.). London: Routledge.

Grimes, D., \& Warschauer, M. (2008). Learning with laptops: A multi-method case study. Journal of Educational Computing Research, 38(3), 305-332. https://doi.org/10.2190/EC.38.3.d

Gutiérrez, K. D. (2008). Developing a sociocritical literacy in the third space. Reading Research Quarterly, 43(2), 148-164.

Habermas, J. (1981). The theory of communicative action: Reason and the rationalization of society (Vol. 1). Boston, MA: Beacon Press.

Halliday, M. A. K. (1978). Language as social semiotic: The social interpretation of language and meaning. Maryland. University Park Press.

Halliday, M. A. K. (1993). Towards a language-based theory of learning. Linguistics and Education, 5(2), 93-116. 
Hassett, D. D., \& Curwood, J. S. (2009). Theories and practices of multimodal education: The instructional dynamics of picture books and primary classrooms. The Reading Teacher, 63(4), 270-282. https://doi.org/10.1598/RT.63.4.2

Hesterman, S. (2011a). Multiliterate Star Warians: The force of popular culture and ICT in early learning. Australian Journal of Early Childhood, 36(4), 86-95.

Hesterman, S. (2011b). A contested space: The dialogic intersection of ICT, multiliteracies, and early childhood. Contemporary Issues in Early Childhood, 12(4), 349-361. https://doi.org/10.2304/ciec.2011.12.4.349

Hesterman, S. (2013). Early childhood designs for multiliteracies learning. Australian Journal of Language and Literacy, 36(3), 158-168.

Hill, S. (2010). The millennium generation: Teacher-researchers exploring new forms of literacy. Journal of Early Childhood Literacy, 10(3), 314-340. https://doi.org/10.1177/1468798410372820

Hsieh, H., \& Shannon, S. E. (2005). Three approaches to Qualitative Content Analysis. Qualitative Health Research 15(9), 1277-1288. https://doi.org/10.1177/1049732305276687

Hughes, J. M., \& Morrison, L. (2014). The impact of social networking and a multiliteracies pedagogy on English language learners' writer identities. Writing \& Pedagogy, 6(3), 607-631. https://doi.org/10.1558/wap.v6i3.607

Ikpeze, C. H. (2012). New kids on the block: Understanding and engaging elementary readers and writers in new times. Journal of School Connections, 4(1), 3-24.

Ivanič, R. 2004. Discourses of writing and learning to write. Language and Education, $18(3), 220-245$.

Jewitt, C., \& Kress, G. (2003). Multimodal literacy. New York: Peter Lang.

Kalantzis, M., \& Cope, B. (2012). Literacies. Cambridge: Cambridge University Press.

Kauppinen, M. 2010. Lukemisen linjaukset. [Literacy delineated-reading literacy and its' instruction in the curricula for the mother tongue in basic education]. Jyväskylä Studies in Humanities 141. Jyväskylä: University of Jyväskylä.

Kervin, L. (2009). 'GetReel': Engaging year 6 students in planning, scripting, actualising and evaluating media text. Literacy, 43(1), 29-35. https://doi.org/10.1111/j.17414369.2009.00513.x

Kitson, L., Fletcher, M., \& Kearney, J. (2007). Continuity and change in literacy practices: A move towards multiliteracies. The Journal of Classroom Interaction, 41/42, 29-41.

Koren, Y., Klavir, R., \& Gorodetsky, M. (2005). Students' multi-modal re-presentations of scientific knowledge and creativity. The Journal of Creative Behavior, 39(3), $191-212$.

Kress, G. (2003) Literacy in the new media age. London: Routledge.

Kress, G. (2010). Multimodality: A social semiotic approach to contemporary communication (1st ed.). London, New York: Routledge.

Kulju, P., Kauppinen, M., Hankala, M., Harjunen, E., Pentikäinen, J. \& Routarinne, S. (2017). Reviewing Finnish studies on writing in basic education: Towards a pedagogy for diversity. In N. Pyyry, L. Tainio, K. Juuti, R. Vasquez \& M. Paananen (Eds.), Changing subjects, changing pedagogies: Diversities in school and education (pp. 110-127). Studies in Subject Didactics 13. Publications of the Finnish Research Association for Subject Didactics. 
Lambert, W. (1974). Culture and language as factors in learning and education. In F. E.

Abour and R. D. Meade (Eds.), Cultural factors in learning and education (pp. 91-122). Bellingham, WA: 5th Western Washington Symposium on Learning.

Lankshear, C. (with Gee, J. P., Knobel, M., \& Searle, C.). (1997). Changing literacies.

Philadelphia, PA: Open University Press.

Lankshear, C., \& Knobel, M. 2003. New literacies: Changing knowledge and classroom learning. Philadelphia: Open University Press.

Lankshear, C., \& Knobel, M. 2011. New literacies: Changing knowledge and classroom learning (3rd ed.). New York: Open University Press.

Lave, J., \& Wenger, E. (1991). Situated learning: Legitimate peripheral participation. Cambridge: Cambridge University Press.

Lawson, H., Layton, L., Goldbart, J., Lacey, P., \& Miller, C. (2012). Conceptualisations of literacy and literacy practices for children with severe learning difficulties. Literacy, 46(2), 101-108. https://doi.org/10.1111/j.1741-4369.2011.00603.x

Leander, K., \& Boldt, G. (2013). Rereading "a pedagogy of multiliteracies": Bodies, text, and emergence. Journal of Literacy Research, (45)1, 22-46. https://doi.org/10.1177/1086296X12468587

Leu, D. J., Kinzer, C. K., Coiro, J., Castek, J. \& Henry, L. (2004). New literacies: A duallevel theory in the changing nature of literacy, instruction, and assessment. In R. B. Ruddell \& N. J. Unrau (Eds.), Theoretical models and processes of reading (5th ed., pp. 1570-1613). Newark, DE: International Reading Association.

Lotherington, H. (2007). Rewriting traditional tales as multilingual narratives at elementary school: Problems and progress. Canadian Journal of Applied Linguistics/Revue Canadienne de Linguistique Appliquée, 10(2), 241-256.

Lotherington, H., \& Chow, S. (2006). Rewriting "Goldilocks" in the urban, multicultural elementary school. The Reading Teacher, 60(3), 244-252. https://doi.org/10.1598/RT.60.3.4

Lotherington, H., Holland, M., Sotoudeh, S., \& Zentena, M. (2008). Project-based community language learning: Three narratives of multilingual story-telling in early childhood education. Canadian Modern Language Review, 65(1), 125-145. https://doi.org/10.3138/cmlr.65.1.125

Luke, A., \& Freebody, P. (1997). Shaping the social practices of reading. In S.

Muspratt, A. Luke. \& P. Freebody (Eds.), Constructing critical literacies: Teaching and learning textual practice (pp. 185-225). Sydney: Allen \& Unwin.

Marshall, E., \& Toohey, K. (2010). Representing family: Community funds of knowledge, bilingualism, and multimodality. Harvard Educational Review, 80(2), 221-242. https://doi.org/10.17763/haer.80.2.h3446j54n608q442

Mavers, D. (2009). Student text-making as semiotic work. Journal of Early Childhood Literacy, 9(2), 145-160. https://doi.org/10.1177/1468798409105584

Maxwell, J. A. (2012). Qualitative research design: An interactive approach. Thousand Oaks, CA: Sage.

McClay, J. K. (2006). Collaborating with teachers and students in multiliteracies research: "Se hace camino al andar". Alberta Journal Of Educational Research, 52(3), 182-195.

Merchant, G. (2005). Digikids: Cool dudes and the new writing. E-learning and Digital Media, 2(1), 50-60. 
Mills, K. A. (2006a). "Mr Travelling-at-will Ted Doyle": Discourses in a multiliteracies classroom. Australian Journal of Language and Literacy, 29(2), 132-149.

Mills, K. A. (2006b). "We've been wastin'a whole million watchin'her doin'her shoes": Situated practice within a pedagogy of multiliteracies. The Australian Educational Researcher, 33(3), 13-32. https://doi.org/10.1007/BF03216840

Mills, K. A. (2007a). Access to multiliteracies: A critical ethnography. Ethnography and Education, 2(3), 305-325. https://doi.org/10.1080/17457820701547310

Mills, K. A. (2007b). "Have you seen Lord of the Rings?” Power, pedagogy, and discourses in a multiliteracies classroom. Journal of Language, Identity, and Education, 6(3), 221-241. https://doi.org/10.1080/15348450701454247

Mills, K. A., \& Exley, B. (2014). Time, space, and text in the elementary school digital writing classroom. Written Communication, 31(4), 434-469. https://doi.org/10.1177/0741088314542757

Mills, K. A. (2011). "Now I know their secrets": Kineikonic texts in the literacy classroom. Australian Journal of Language and Literacy, 34(1), 24-37.

Mills, Kathy A. (2016). Literacy theories for the digital age: Social, critical, multimodal, spatial, material and sensory lenses. New Perspectives in Language and Education. Multilingual Matters, Bristol, United Kingdom [Kindle iPad version]. Retrieved from http://www.amazon.com.

Mitchel, W. J. T. (2015). Image science. Iconology, visual culture, and media aesthetics. Chicago: The University of Chicago Press.

NCC (2016), National Core Curriculum for Basic Education 2014. Finnish National Board of Education. 2016:5, Available from: Apple iBook.

New London Group. (1996). A pedagogy of multiliteracies: Designing social futures. Harvard Educational Review, 66(1), 60-92.

NGA \& CCSO (National Governors Association Center for Best Practises \& Council of Chief State School Officers). (2010). Common core state standards for English language arts \& literacy in history/social studies, science, and technical subjects. Washington, DC: Author.

Ontario Ministry of Education. (2006). The Ontario Curriculum Grades 1-8 Language. http://www.edu.gov.on.ca/eng/curriculum/elementary/language18currb.pdf

Pahl, K. (2005). Literacy and education: Understanding the new literacy studies in the classroom. London: Chapman.

Pahl, K. (2007). Creativity in events and practices: A lens for understanding children's multimodal texts Literacy, 41(2), 86-92. https://doi.org/10.1111/j.14679345.2007.00462.x

Pahl, K. (2009). Interactions, intersections and improvisations: Studying the multimodal texts and classroom talk of six to seven year olds Journal of Early Childhood Literacy, 9(2), 188-210. https://doi.org/10.1177/1468798409105586

Palmer, D. (2010). Race, power, and equity in a multiethnic urban elementary school with a dual-language "strand" program. Anthropology \& Education Quarterly, 41(1), 94-114. https://doi.org/10.1111/j.1548-1492.2010.01069.x

Palsa, L., \& Ruokamo, H. (2015). Behind the concepts of multiliteracies and media literacy in the renewed Finnish core curriculum: A systematic literature review of peer-reviewed research. Seminar.net-International Journal of Media, Technology and Lifelong Learning, 11(2), 101-118. 
Pantaleo, S. (2013). Paneling "matters" in elementary students' graphic narratives. Literacy Research and Instruction, 52(2), 150-171. https://doi.org/10.1080/19388071.2012.754973

Pendleton, M. (2013). Through the lens: Multimodal science, math, and literacy practices in an elementary classroom. Meridian: A K-16 School Computer Technologies Journal, 16(1), 1-12.

Pittaway, L. (2007). Systematic literature reviews. In R. Thorpe \& R. Holt (Eds.), The Sage dictionary of qualitative management research (pp. 216-218). Los Angeles: Sage Publications.

Ranker, J. (2007). Designing meaning with multiple media sources: A case study of an eight-year-old student's writing processes. Research in the Teaching of English, 41(4), 402-434.

Ranker, J. (2008). Composing across multiple media: A case study of digital video production in a fifth grade classroom. Written Communication, 25(2), 196-234.

Ridgewell, J., \& Exley, B. (2011). The potentials of student initiated netspeak in a middle primary science-inspired multiliteracies project. Research in Science Education, 41(5), 635-649. https://doi.org/10.1007/s11165-010-9183-4

Rossi, P. J. (1997). Having an experience in five acts: Multiple literacies through young children's opera. Language Arts, 74(5), 352-367.

Ryan, M. E., \& Anstey, M. (2003). Identity and text: Developing self-conscious readers. Australian Journal of Language and Literacy, 26(1), 9-22.

Serafini, F., \& Ladd, S. M. (2008). The challenge of moving beyond the literal in literature discussions. Journal of Language and Literacy Education, 4(2), 6-20.

Siegel, M., Kontovourki, S., Schmier, S., \& Enriquez, G. (2008). Literacy in motion: A case study of a shape-shifting kindergartener. Language Arts, 86(2), 89-98.

Silvers, P., Shorey, M., \& Crafton, L. (2010). Critical literacy in a primary multiliteracies classroom: The Hurricane Group. Journal of Early Childhood Literacy, 10(4), 379-409. https://doi.org/10.1177/1468798410382354

Taylor, L. K., Bernhard, J. K., Garg, S., \& Cummins, J. (2008). Affirming plural belonging: Building on students' family-based cultural and linguistic capital through multiliteracies pedagogy. Journal of Early Childhood Literacy, 8(3), 269-294._https://doi.org/10.1177/1468798408096481

Van Leeuwen, T. (2005). Introducing social semiotics. New York: Routledge.

Vygotsky, L. S. (1962). Thought and language. Cambridge MA: MIT Press.

Walsh, M. (2006). The "textual shift": Examining the reading process with print, visual and multimodal texts. Australian Journal of Language and Literacy, 29(1), 2437.

Wedin, Å. (2010). Narration in Swedish pre-and primary school: A resource for language development and multilingualism. Language, Culture and Curriculum, 23(3), 219-233. https://doi.org/10.1080/07908318.2010.515995

Wohlwend, K. E. (2009). Early adopters: Playing new literacies and pretending new technologies in print-centric classrooms. Journal of Early Childhood Literacy, 9(2), 117-140._https://doi.org/10.1177/1468798409105583

Zammit, K. P. (2011). Connecting multiliteracies and engagement of students from low socio-economic backgrounds: Using Bernstein's pedagogic discourse as a bridge. 
Language and Education, 25(3), 203-220.

https://doi.org/10.1080/09500782.2011.560945

\section{APPENDIX 1}

\section{ARTICLE LIST $(\mathrm{N}=67)$}

Ajayi, L. (2011). A multiliteracies pedagogy: Exploring semiotic possibilities of a Disney video in a third grade diverse classroom. The Urban Review, 43(3), 396-413. https://doi.org/10.1007/s11256-010-0151-0

Albers, P. (2009). Reading students' visual texts created in English language arts classrooms. Language Arts Journal of Michigan, 25(1), 6-16. https://doi.org/10.9707/2168-149X.1083

Albers, P., Frederick, T. \& Cowan, K. (2009). Features of gender: An analysis of the visual texts of third grade students. Journal of Early Childhood Literacy, 9(2), 243-269. https://doi.org/10.1177/1468798409105588

Bomer, R. Zoch, M. P., David, A. D. \& Ok, J. (2010). New literacies in the material world. Language Arts, 88(1), 62-68.

Callow, J. (2003). Talking about visual texts with students. Reading online, 6(8), 1-16.

Callow, J. (2006). Images, politics and multiliteracies: Using a visual metalanguage. Australian Journal of Language and Literacy, 29(1), 7-23.

Coleman, J. M., Bradley, L. G., \& Donovan, C. A. (2012). Visual representations in second graders' information book compositions. The Reading Teacher, 66(1), 3145. https://doi.org/10.1002/TRTR.01100

Comber, B., Thomson, P., \& Wells, M. (2001). Critical literacy finds a "place": Writing and social action in a low-income Australian grade 2/3 classroom. The Elementary School Journal, 101(4), 451-464.

Crafton, L. K., Silvers, P., \& Brennan, M. (2009). Creating a critical multiliteracies curriculum: Repositioning art in the early childhood classroom. In M. Narey (Ed.), Making meaning Constructing multimodal perspectives on language, literacy and learning through art-based early childhood education, (pp. 31-51). Springer US. https://doi.org/10.1007/978-0-387-87539-2_3

Cumming-Potvin, W. (2007). Scaffolding, multiliteracies, and reading circles. Canadian Journal of Education/Revue Canadienne de l'Education, 30(2), 483-507. https://doi.org/10.2307/20466647

Cummins, J., Bismilla, V., Cohen, S., Giampapa, F., \& Leoni, L. (2005). Rethinking literacy instruction in multilingual classrooms. Orbit, 36(1), 22-26.

Cummins, J., Bismilla, V., Chow, P., Cohen, S., Giampapa, F., Leoni, L., ... Sastri, P. (2005). Affirming identity in multilingual classrooms. Educational Leadership, 63(1), 38-43.

Del-Castillo, H., García-Varela, A. B., \& Lacasa, P. (2003). Literacies through media: identity and discourse in the process of constructing a web site. International Journal of Educational Research, 39(8), 885-891. https://doi.org/10.1016/j.ijer.2004.11.010 
Doherty, C. (2002). Extending horizons: Critical technological literacy for urban Aboriginal students. Journal of Adolescent \& Adult Literacy, 46(1), 50-59.

Emery, W., \& McCabe, R. (2003). The development of media literacy among grade five teachers and students-A case study. Canadian Journal of Learning and Technology, 29(1), 39-66.

Fisher, T. R., Albers, P., \& Frederick, T. G. (2014). When pictures aren't pretty: Deconstructing punitive literacy practices. Journal of Early Childhood Literacy, 14(3), 291-318. https://doi.org/10.1177/1468798413485267

Grimes, D., \& Warschauer, M. (2008). Learning with laptops: A multi-method case study. Journal of Educational Computing Research, 38(3), 305-332. https://doi.org/10.2190/EC.38.3.d

Hassett, D. D., \& Curwood, J. S. (2009). Theories and practices of multimodal education: The instructional dynamics of picture books and primary classrooms. The Reading Teacher, 63(4), 270-282. https://doi.org/10.1598/RT.63.4.2

Hesterman, S. (2011a). Multiliterate Star Warians: The force of popular culture and ICT in early learning. Australian Journal of Early Childhood, 36(4), 86-95.

Hesterman, S. (2011b). A contested space: The dialogic intersection of ICT, multiliteracies, and early childhood. Contemporary Issues in Early Childhood, 12 (4), 349-361. https://doi.org/10.2304/ciec.2011.12.4.349

Hesterman, S. (2013). Early childhood designs for multiliteracies learning. Australian Journal of Language and Literacy, 36(3), 158-168.

Hill, S. (2010). The millennium generation: Teacher-researchers exploring new forms of literacy. Journal of Early Childhood Literacy, 10(3), 314-340. https://doi.org/10.1177/1468798410372820

Hughes, J. M., \& Morrison, L. (2014). The impact of social networking and a multiliteracies pedagogy on English language learners' writer identities. Writing \& Pedagogy, 6(3), 607-631. https://doi.org/10.1558/wap.v6i3.607

Husbye, N. E., Buchholz, B., Coggin, L. S., Powell, C. W., \& Wohlwend, K. E. (2012). Critical lessons and playful literacies: Digital media in PK-2 classrooms. Language Arts, 90(2), 82-92.

Ikpeze, C. H. (2012). New kids on the block: Understanding and engaging elementary readers and writers in new times. Journal of School Connections, 4(1), 3-24.

Jones, A. (2008). Multimedia and multiliteracies in the early elementary years. In J. Luca \& E. Weippl (Eds.), Proceedings of EdMedia: World Conference on Educational Media and Technology 2008 (pp. 2942-2948). Association for the Advancement of Computing in Education (AACE).

Kervin, L. (2009). 'GetReel': Engaging year 6 students in planning, scripting, actualising and evaluating media text. Literacy, 43(1), 29-35. https://doi.org/10.1111/j.17414369.2009.00513.x

Kervin, L. K., \& Mantei, J. (2006). Visions for literacy learning: The quest for meaningful use of computer-based technology in reading and writing experiences. In J. Rennie (Ed.), Voices, Vibes, Visions AATE/ALEA National Conference 2006 Proceedings. Australia: Australian Literacy Educator's Association/The Australian Association for the Teaching of English. 
Kitson, L., Fletcher, M., \& Kearney, J. (2007). Continuity and change in literacy practices: A move towards multiliteracies. The Journal of Classroom Interaction, 41/42, 29-41.

Koren, Y., Klavir, R., \& Gorodetsky, M. (2005). Students' multi-modal re-presentations of scientific knowledge and creativity. The Journal of Creative Behavior, 39(3), 191-212.

Lawson, H., Layton, L., Goldbart, J., Lacey, P., \& Miller, C. (2012). Conceptualisations of literacy and literacy practices for children with severe learning difficulties. Literacy, 46(2), 101-108. https://doi.org/10.1111/j.1741-4369.2011.00603.x

Lotherington, H. (2007). Rewriting traditional tales as multilingual narratives at elementary school: Problems and progress. Canadian Journal of Applied Linguistics/Revue Canadienne de Linguistique Appliquée, 10(2), 241-256.

Lotherington, H., \& Chow, S. (2006). Rewriting "Goldilocks" in the urban, multicultural elementary school. The Reading Teacher, 60(3), 244-252. https://doi.org/10.1598/RT.60.3.4

Lotherington, H., Holland, M., Sotoudeh, S., \& Zentena, M. (2008). Project-based community language learning: Three narratives of multilingual story-telling in early childhood education. Canadian Modern Language Review, 65(1), 125-145. https://doi.org/10.3138/cmlr.65.1.125

Marshall, E., \& Toohey, K. (2010). Representing family: Community funds of knowledge, bilingualism, and multimodality. Harvard Educational Review, 80(2), 221-242. https://doi.org/10.17763/haer.80.2.h3446j54n608q442

Mavers, D. (2009). Student text-making as semiotic work. Journal of Early Childhood Literacy, 9(2), 145-160. https://doi.org/10.1177/1468798409105584

McClay, J. K. (2006). Collaborating with teachers and students in multiliteracies research: "Se hace camino al andar". Alberta Journal Of Educational Research, 52(3), 182-195.

Merchant, G. (2005). Digikids: Cool dudes and the new writing. E-learning and Digital Media, 2(1), 50-60.

Mills, K. A. (2006a). "Mr Travelling-at-will Ted Doyle": Discourses in a multiliteracies classroom. Australian Journal of Language and Literacy, 29(2), 132-149.

Mills, K. A. (2006b). "We've been wastin'a whole million watchin'her doin'her shoes": Situated practice within a pedagogy of multiliteracies. The Australian Educational Researcher, 33(3), 13-32. https://doi.org/10.1007/BF03216840

Mills, K. A. (2007a). Access to multiliteracies: A critical ethnography. Ethnography and Education, 2(3), 305-325. https://doi.org/10.1080/17457820701547310

Mills, K. A. (2007b). "Have you seen Lord of the Rings?” Power, pedagogy, and discourses in a multiliteracies classroom. Journal of Language, Identity, and Education, 6(3), 221-241. https://doi.org/10.1080/15348450701454247

Mills, K. A. (2011). "Now I know their secrets": Kineikonic texts in the literacy classroom. Australian Journal of Language and Literacy, 34(1), 24-37.

Mills, K. A., \& Exley, B. (2014). Time, space, and text in the elementary school digital writing classroom. Written Communication, 31(4), 434-469. https://doi.org/10.1177/0741088314542757 
Murray, B. (2014). Finding strength: Multimodal assessment and adaptation of children's writing into theatre. Youth Theatre Journal, 28(2), 165-180. https://doi.org/10.1080/08929092.2014.956957

Nixon, H. (1999). Towards a (cyber) pedagogy for multimedia multiliteracies. Teaching Education, 10(2), 87-102. https://doi.org/10.1080/1047621990100210

Ntelioglou, B. Y., Fannin, J., Montanera, M., \& Cummins, J. (2014). A multilingual and multimodal approach to literacy teaching and learning in urban education: A collaborative inquiry project in an inner city elementary school. Frontiers in Psychology, 5, 553. https://doi.org/10.3389/fpsyg.2014.00533

Pahl, K. (2007). Creativity in events and practices: A lens for understanding children's multimodal texts. Literacy, 41 (2), 86-92. https://doi.org/10.1111/j.14679345.2007.00462.x

Pahl, K. (2009). Interactions, intersections and improvisations: Studying the multimodal texts and classroom talk of six to seven year olds Journal of Early Childhood Literacy, 9(2), 188-210. https://doi.org/10.1177/1468798409105586

Palmer, D. (2010). Race, power, and equity in a multiethnic urban elementary school with a dual-language "strand" program. Anthropology \& Education Quarterly, 41(1), 94-114. https://doi.org/10.1111/j.1548-1492.2010.01069.x

Pantaleo, S. (2013). Paneling "matters" in elementary students' graphic narratives. Literacy Research and Instruction, 52(2), 150-171. https://doi.org/10.1080/19388071.2012.754973

Pendleton, M. (2013). Through the lens: Multimodal science, math, and literacy practices in an elementary classroom. Meridian: A K-16 School Computer Technologies Journal, 16(1), 1-12.

Ranker, J. (2007a). Designing meaning with multiple media sources: A case study of an eight-year-old student's writing processes. Research in the Teaching of English, 41(4), 402-434.

Ranker, J. (2007b). Using comic books as read-alouds: Insights on reading instruction from an English as a Second Language classroom. The Reading Teacher, 61(4), 296-305. https://doi.org/10.1598/RT.61.4.2

Ranker, J. (2008). Composing across multiple media: A case study of digital video production in a fifth grade classroom. Written Communication, 25(2), 196-234. https://doi.org/10.1177/0741088307313021

Ridgewell, J., \& Exley, B. (2011). The potentials of student initiated netspeak in a middle primary science-inspired multiliteracies project. Research in Science Education, 41(5), 635-649. https://doi.org/10.1007/s11165-010-9183-4

Rossi, P. J. (1997). Having an experience in five acts: Multiple literacies through young children's opera. Language Arts, 74(5), 352-67.

Ryan, M. E., \& Anstey, M. (2003). Identity and text: Developing self-conscious readers. Australian Journal of Language and Literacy, 26(1), 9-22.

Serafini, F. \& Ladd, SM (2008). The challenge of moving beyond the literal in literature discussions. Journal of Language and Literacy Education, 4(2), 6-20.

Siegel, M., Kontovourki, S., Schmier, S., \& Enriquez, G. (2008). Literacy in motion: A case study of a shape-shifting kindergartener. Language Arts, 86(2), 89-98. 
Silvers, P., Shorey, M., \& Crafton, L. (2010). Critical literacy in a primary multiliteracies classroom: The Hurricane Group. Journal of Early Childhood Literacy, 10(4), 379-409. https://doi.org/10.1177/1468798410382354

Taylor, L. K., Bernhard, J. K., Garg, S., \& Cummins, J. (2008). Affirming plural belonging: Building on students' family-based cultural and linguistic capital through multiliteracies pedagogy. Journal of Early Childhood Literacy, 8(3), 269-294._https://doi.org/10.1177/1468798408096481

Torres, C. A., \& Souza, J. (2005). I will count my sheep: Creativity and the "Everyday Life Project." Action, Criticism, and Theory for Music Education, 4(2), 1-15.

Wedin, Å. (2010). Narration in Swedish pre-and primary school: A resource for language development and multilingualism. Language, Culture and Curriculum, 23(3), 219-233. https://doi.org/10.1080/07908318.2010.515995

Wohlwend, K. E. (2009). Early adopters: Playing new literacies and pretending new technologies in print-centric classrooms. Journal of Early Childhood Literacy, 9(2), 117-140. https://doi.org/10.1177/1468798409105583

Zammit, K. (2010). The New Learning Environments framework: Scaffolding the development of multiliterate students. Pedagogies: An International Journal, 5(4), 325-337. https://doi.org/10.1080/1554480X.2010.509479

Zammit, K. P. (2011). Connecting multiliteracies and engagement of students from low socio-economic backgrounds: Using Bernstein's pedagogic discourse as a bridge. Language and Education, 25(3), 203-220. https://doi.org/10.1080/09500782.2011.560945 